\title{
Characteristics of Undeclared Work in Service Sector in Countries of South East Europe
}

\author{
Predrag Bejaković * \\ Ruslan Stefanov ${ }^{* *}$
}

\begin{abstract}
The undeclared work is a complex and multifaceted phenomenon that has been present in all countries, regardless of its social and political establishment. Notwithstanding, the empirical evidence suggests that informal economy is more prevalent in countries with lower levels of GDP. Furthermore, the informal economy is present in sectors with lower level of capital and higher level of labour intensity. Therefore, the theory and everyday experience imply that the informal economy is more widespread among the services than the goods sectors. This paper provides an overview on the informal work and unofficial economy in the services sector in the former socialist countries in South East Europe. For the reduction of undeclared activities, it is necessary to simplify the procedures for establishing small businesses, to stabilize the tax system, to ensure high tax morale and trust in society and towards institutions, and to decrease the state regulatory burden.
\end{abstract}

Keywords: undeclared work; post-transition; South East Europe; service sector

JEL Classification: E 26, L83, O17, Z31

\section{Introduction}

The unofficial work or hidden economy thrived in the history of civilisation. It was extensive in the former Communist countries and nowadays it is getting more widespread in rich post-industrial countries (Feige, 1983; Feige, 1990; Jankov, 1997; Feige \& Ott, 1999). Harding and Jenkins (1989) believe that the differences between the informal economic activities of liberal Western capitalistic counties, planned social-

\footnotetext{
${ }^{*}$ Predrag Bejaković is at Institute of Public Finance, Zagreb, Croatia.

${ }^{* * *}$ Ruslan Stefanov is at Vitosha Research, Sofia, Bulgaria.
} 
ist countries, and relatively non-regulated economies of the Third World are not only of formal nature and of state organisation and intervention. These are all essentially different systems. If one wants to understand their functioning and links between the formal and the informal economy, he should have to use different analytical frameworks, which would identify distinctiveness of the different political, social and economic systems.

The economies can be grouped as socialist planned, market and developing of the Third World. In this text, we provide an overview on the causes and characteristics of the undeclared work within previously socialist countries in the South East Europe. Although former socialist states accepted market economy more than 25 years ago, many characters and legacies of the planned socialistic system in their current policies and population expectations are obvious (Franicevic \& Kraft, 1996). The characters of the past system are echoed also in the behaviour of decision makers that are incline to regulate and directly influence all economic activities (Madzarevic-Sujster $\&$ Mikulic, 2002; Schneider, 2011). These characters also influence the behaviour of the citizens, which quite often disrespects the rule of law and have a low level of trust in the Government and its policies (Kaufmann \& Kaliberda, 1996; Vincensini, 2001).

The "unofficial" or "informal" economic activities are usually defined in accordance with numerous principles and changeable criteria (ILO, 2002; ILO, 2014). According to legality approach, it is generally illegal economy (Feige, 1987). Having in mind the moral approach, it is underground or immoral, because it breaks the accepted business rules (Feige, 1990). Regarding the institutional approach, these are unrecorded activities, since achieved business revenues are kept off records and thus not being included in the official statistics (Feige, 1979; Feige, 1983; Feige \& Ott, 1999). Regarding the quantitative approach, it is immeasurable, as informal work can be quantified in a certain way but these activities have not be assessed previously (Feige, 1979). Finally, there is an ideological approach, which depends mostly on the predominant economic and political system (Feige, 1987). According to the broader definition, informal work and unofficial economy incorporate all economic activities that are publicly thought inconsistent when compared to prevailing ideological system of economic and political organization of the society (Feige, 1983; Feige, 1997; ILO 2002; Williams, 2014). The narrower definition explains that informal work includes various business activities of households, individual barter transactions and do-it-yourself activities (Franz, 1984; OECD, 2002).

The term undeclared work denotes those economic activities that for various reasons are not included in administrative and tax data or the statistics business surveys applied in the preparation of national accounts. Various international definitions (OECD, 2002, p.13), define informal production includes as "those activities that are productive and legal but are deliberately concealed from the public authorities to avoid payment of taxes or complying with regulations". Here are also included illegal productive activities that generate different goods and services not allowed by law or 
that are illicit when performed by unauthorised producers as well as informal sector production. With definition of informal economy, which is because of its nature almost impossible to measure, the researcher of the informal work faces the same problem as Justice Potter Stewart with the definition of obscenity. Therefore, one can apply his famous sentence: "I know it, when I see it" (Bryson, 2004).

Informal work is a complex and multifaceted phenomenon, which exists independently from social and political systems within countries. However, the form and structure of unofficial economy differentiate among countries due to distinct levels of economic development and certain institutional factors. The informal work in rich developed economies is mostly used for lowering production costs and prices. Gershuny (1979) believes that this is done primarily through evasion of fiscal obligation as well as avoidance of some legal limitations and regulations (for example, not respecting labour regulation). In socialistic planned economies, the informal economic activities are used for provision of scarce or better quality goods thus correcting existing market failures (Grossman, 1977; Grossman \& Treml, 1987). In relatively poor developing countries, the unofficial work did not evolve as a correction mechanism for solving the problems of unemployment nor because of strict legal regulation (ILO, 1985; Bacchetta et al., 2009). Within those countries, the informal economy is a resultant of poor economic development and coexistence of dissimilar economic structures (Glas, 1988).

This paper provides an outline of the characteristics of informal work in the former socialist countries of South East Europe. In the analysis of the informal economy in the observed countriesThe rest of the paper is organised as follows. Section 1 deals with the importance of informal work in services sector and various methods of measuring the informal economy, while Section 2 deals with the informal work in formerly socialistic countries. Section 3 provides on overview of the situation in the selected post-socialist economies in the South East Europe. Finally, section 4 contains conclusion and recommendations.

\section{The Significance of Informal Work in Services Sector and its Measurement}

OECD (2007, p. 261), defines informal work as “...jobs or activities in the production and commercialization of legal goods and services not registered or protected by the state. Informal workers are excluded from social security benefits and the protection afforded by formal labour contracts. The majority cannot opt for better jobs, which are scarce in the formal sector. Others voluntarily opt out of the formal system. For them, the savings from being fully or partly informal - no social security contributions, no tax payments, no binding labour regulations and more freedom for business activities - outweigh the benefits accrued through registration and compliance." Perry et al. (2007) separate the informal work into two groups: informal wages and salaries 
on one side, and informal independent work on another. The informal salaried labour encompasses unpaid and domestic workers, which are often women. The informal self-employed (independent) workers are mostly single-person companies or owners employing other workers.

Although in the majority of advanced post-transitional societies the volume of the unofficial economy is generally not large, neglecting this phenomenon can have severe negative consequences (Bejakovic, 2015). It can cause insufficient collection of public revenues and/or create disproportion and wrong data in different items of the national accounts (Feige, 1979; CSD, 2011). The statistical accounts could then be a source of misleading information based on which preparation and implementation of incorrect national economic and political measures could happen. Furthermore, widespread and deeply rooted informal economy may lead to changes in social distribution causing increase of income disparities.

The role and structure of the present informal work may be very useful milestone for comparative analysis of reform processes in post-socialist countries and/or countries trying to achieve economic and social development. Analysis suggests that the role and structure of the informal work in a society experiencing an economic and political change may be an important signal for assessing how successful the reforms are (Gibson, 2013). The informal work also has an adverse effect on the successful design and implementation of economic policies. The greater the informal work is, the greater is its influence on the economic policies. Hence, in the majority of countries estimates concerning the growth of informal work are probably more important than estimates of its volume (Feige \& Ott, 1999).

Various methods of an estimation of the size of the informal economy are following:

- direct methods - questionnaires by post, mail or Web, face to face and telephone interviews, focus group discussions, detail control of tax returns and use of tax statistics and experts' estimation on the situation in a particular economic sector

- indirect methods - a macro approach or difference between revenues and expenditures on the level of the national economy, a micro discrepancy approach using difference between receipts and expenditures, labour market approach by comparing the activity rates, cash in circulation, transaction method, use of physical inputs method, like electricity

- Causal methods - determinants and indicators - DYMIMIC and demand for cash

- Eurostat approach - Exhaustiveness of national accounts

The various methods have different advantages and disadvantages (Easton, 2001; Schneider and Enste, 2000; Galić Nagyszombaty, 2012; OECD 2002) and can for the same country and the same period produce diverse results (Schneider 2005, 2012; Bejaković, 2017). However, much more important of the level, is the trend, or does the informal economy increase or decrease during the observed period. 


\section{The Informal Economy in Planned Economies}

Entrepreneurs in circumstances of capitalist economies face a higher level of customer mistrust and more difficulties with distribution conditions (Cassel \& Cichy, 1987; Dallago, 1987; Perry et al., 2007). An entrepreneur can only be successful if the selling price, quality and time spent on the product/service he or she is producing are better than those of his or her competitors. Almost none of these elements has any significance in socialist societies where the prices are in majority inelastic due to the chronic lack of the goods in the market (Grossman, 1977; Grossman \& Treml, 1987). The informal work and unofficial economy had a crucial role in solving the problems of constant and large shortages in these societies.

A number of factors had influence on the establishment and development of the informal work in former socialist countries. They can be divided in three sub-groups - social, economic and political. Some of the most significant social factors are: a) low living standard that motivated and/or encouraged citizens for participation in unofficial activities; b) relatively high level of unemployment that was often above the average level of unemployment in developed countries; and c) regional differences in the economic development which motivates migration and acceptance of informal work in capital or bigger cities (Feige \& Urban, 2008; Johnson et al., 1997; Karaic, 2002).

Some of the most vital economic factors are: a) restructuring processes (i.e. transition process itself) that was developed spontaneously and often under direct and strong influence and control of policy decision makers and/or groups that have supervised transition process; b) spontaneous privatization where the interests of social groups that did not sufficiently benefit from privatization, were not taken into consideration; c) confusing, unstable, and complex tax systems and policies, where most of them were designed to achieve rapid impact towards increasing budget revenues without thinking about long-term impacts (Feige, 1997; Feige \& Ott, 1999; Franicevic, 1999; Franicevic \& Kraft, 1996).

The most important political factors comprise: a) unfinished legislation framework and the weak coordination, low degree of political liberalization versus high level of repression; and b) low level of judicial and public service expertise and education (Franicevic, 1999). In the design and implementation of various transition measures, the majority of the mentioned factors was not taken into consideration.

According to Grossman (1977), the "second" or underground economy in socialistic economies was caused by the desire to gain personal profit and to work, in a certain way, against the existing legislation. O'Hearn (1980) claims that such definition is too narrow because it does not include different types of the informal economy, which are contrary to the plans in the legal socialist sector. The unofficial economy in a planned socialistic society includes all activities not included into the planning 
process and not recognized as a part of the national economy. Sweezy (1980) defines the parallel or informal economy as production and economic transaction of goods and services outside the channels defined and approved by the legal scheme. Ericson (1984) broadens the term of the underground or parallel economy to cover all economic activities, which are not in accordance with the idea and norms of central planned socialist system, irrespective of the sector where they are completed.

The occurrence and growth of the underground economy in socialistic countries was reinforced by ideological doubt and distrust in private business initiatives. That resulted in long lasting and complicated administrative procedures for obtaining different and numerous permits (Johnson et al., 1997). An important factor in the development and extent of the unofficial economic activities was also the inadequate development of the service sector. The relatively high tax burden encouraged a large number of economic entities not to report their economic activities or to report them to a lower extent (Feige, 1990; Feige \& Ott, 1999). Thanks to the inefficient organization of the taxation system and the lack of efficient and non-corrupted tax administration, a large part of entrepreneurial activities was realised without the needed documentation and records, predominantly in the services sector (Feige, 1990; Johnson et al., 1997; Sweezy, 1980; Williams \& Martínez, 2014).

Additional reasons that influenced the development of the underground economy in former socialist societies were related to excessively restrictive, inflexible and complex labour legislation (Grossman \& Treml, 1987; Shelley, 1990). In such environment, it was almost impossible to hire a person for several hours per week or to employ a retired person and/or students (Grossman \& Treml, 1987; Shelley, 1990). Moreover, the unofficial sector grew stronger because of inadequate trade union organisation and their weak engagement. The unions in these countries were the prolonged hand of the ruling party and not independent entities, which would really represent and protect the interests of the workers (Williams \& Schneider, 2016).

Even though the socialistic economies were expected to reduce possibilities for unofficial private activities and/or illegally obtained perquisites, the reality was opposite. Many political and social factors stimulated the occurrence and development of unofficial economy. Low wages could not stimulate the workforces to work more intensively and motivated employees to seek additional earnings (Shelley, 1990). Additionally, the state-owned property was unappreciated and underestimated which also caused a distorted attitude toward it (Franicevic \& Kraft, 1996). In that way, the majority of people deemed that taking (stealing) from the state could not be considered a theft, as it would have been the case with the private property (Shelley, 1990). Additionally, the long-lasting "hunger" for all kinds of goods and services resulted in the development of the unofficial black market within the existing formal economy as well as out of its boundaries (Grossman, 1977; Glas, 1988). The hunger for goods and services was caused mostly by centrally planned production, controlled and unreal- 
istic prices and was reinforced by the inappropriate economic management and inadequate distribution (Shelley, 1983). Production was not accustomed to the needs of buyers with regard to quality, diversity, fashion and/or deadlines (Lovrincevic et al., 2002; Lovrincevic et al., 2011). The whole economy was strictly regulated and highly bureaucratised, all of which contributed to the development of the hidden economy.

The notion of informal economy is observed from rather distinctive angles. Thus, in Latin America all activities outside the social security net are labelled informal (Standing, 1991). This idea is inapplicable for former socialist states where state social safety net includes vast majority of activities and individuals. This is somewhat related to the legacy of socialism and partly due to the coexistence of public (state) and non-state activities. Consequently, individuals used state resources as to accomplish their own economic prosperity (Kaufmann \& Kaliberda, 1996).

The informal work in agriculture was the most common form of unofficial activities in previous socialist countries, followed by different types of services related to personal and household care (Lovrincevic et al., 2002). Moreover, services like private tutoring for school subjects and teaching foreign languages were also often performed through informal activities (Lovrincevic et al., 2011). The extensive form of services was the informal construction of houses by professionals and skilled workers (Brezinski, 1983).

Glinkina (1999) studied data on the unofficial economy in 14 post-socialist countries comprising from five Central and Eastern Europe countries and 9 former Soviet Union countries. The total share of the unofficial economy grew from $15 \%$ of overall output to a share exceeding $30 \%$. Consequently, the results show that on average, almost one-third of the economic activities in selected countries were informal. Nevertheless, there are huge variations in the development process and the volume of the unofficial economic activities in the selected countries. The unofficial economy blossomed in Central and Eastern Europe countries in the late 1980s with a share of approximately $20 \%$, while during the same period in former Soviet Union countries it was only $12 \%$. Early nineties led to increase of the unofficial economy in the former Soviet Union countries by almost 24\%, while the level in Central and Eastern Europe countries increased just slightly. Within the first group, the 1994 estimates for the unofficial share vary from $12 \%$ in Uzbekistan to almost $50 \%$ in Ukraine. On the other side, within Central and Eastern Europe countries the informal economy is estimated at $14 \%$ in Czech Republic and double as that (28\%) in Bulgaria. Of course, only part of unofficial economic activities relates to service sector, but there is a close correlation between total level of informal activities and those related to the service sector (Glinkina, 1999).

As mentioned previously, the share of the unofficial economy depends on many factors including the level of political and economic liberalization, and the achievement of macroeconomic stabilization. Uzbekistan did not go through a noteworthy 
economic and political liberalization, while at the same time preserving rigid enforcement instruments. By contrast, during nineties the Czech Republic liberalized its political and economic systems, stabilized its macroeconomic conditions and developed market institutions at a greater pace than other countries in the region. Russia, Kazakhstan, Moldova and Ukraine had the highest share of the unofficial economy among analysed states. Obtained results can be explained by low initial importance of commerce and services in these countries, by lack of macroeconomic stability, by high speed of introduction of political liberalization without any cultural experience and insufficiently developed market institutions. These results suggest that privatization, liberalization and macroeconomic stabilization, which were realised in most of Central and Eastern Europe countries, result in the transfer of informal activities from hidden to official economy. The examples are Hungary, Poland, and Romania where the shares of the informal economy since 1989 have mostly decreased.

While the most frequent workers in the unofficial economy in rich capitalist countries are mostly "marginal workers" (retired persons, housewives and students), in planned and post-transitional planned economies such activities are mostly performed by people that are "regularly" employees in their primary occupation (Gershuny, 1979; Nonchev et al., 2011). There are "strong" and "weak" workers operating in the hidden economy (Dallago, 1987). The "strong" workers are those who are regularly employed, who have knowledge, skills and expertise and those who are regularly and increasingly being sought for and thus being deficient in the market. Their activities in unofficial economy enable them to increase their basic income (Jutting \& de Laiglesia, 2009). On the other hand, as implied by Dallago (1987) the unofficial economy is the only income source for the "weak" workers (e.g. long-term unemployed, people with low education level and scarce employment possibilities, beneficiaries in the social welfare and/or foreign workers without work permits). They use the unofficial economy to assure basic living necessities and to increase disposable income (Gutmann, 1985). It can be assess that "weak" workers like unemployed persons do not find significant advantage even in the unofficial economy, as their obtained education, available skills and knowledge cannot provide them with employment in the formal economy, which makes them relatively unattractive for the unofficial economy as well (Karaic, 2002).

Glinkina (1999) research revealed that there is the contradictory relationship between the unofficial economy and economic development. The informal economy played positive role mitigating the large drop in official GDP of the countries (Feige, 1999). Thus, this "mitigating" effect of the unofficial economy was particularly marked for the former Soviet Union countries. In these countries, about one-half of the decline in official GDP went to informal activities while only one-half was a bona fide decline in national output. This mitigating role of the unofficial economy resulted in both a lower overall GDP decline relative to what the official GDP figures sug- 
gest, as well as significantly lower inter-country variance of the overall GDP declines relative to official GDP (Kaufmann \& Kaliberda, 1996). This example confirms that unofficial activities helped economies to preserve a certain level of national welfare within the framework of high official production costs. The unofficial economy is a very important resource for additional income for citizens (Kaufmann \& Siegelbaum, 1996; Madzarevic-Sujster \& Mikulic, 2002; Stefanov et al., 2017; Williams, 2005; Williams et al., 2013a; Williams et al., 2013b). The presence of incomes from informal sources in countries like Croatia, Macedonia and Serbia helps to decrease income disparities.

However, the existence and growth of unofficial economy might become a severe threat for the achievement of the rule of law as well as for a long-term and sustainable economic development. First, the effective organisation of the economy is hard to obtain and destabilised (Feige, 1999). Transfer of business activities from formal to unofficial channels hurts the tax revenues, impedes macroeconomic stability and tests the legitimacy of the existing regulatory system (Glinkina, 1999) Second, no matter how large the unofficial economy is, it is mostly a "survival strategy" (Jutting $\&$ de Laiglesia, 2009). The revenue flows from unofficial services lead to a focus on short-term turnover that takes over a long-term view. Bigger and more sophisticated investments as well as labour force skilling and education are mostly absent, even though they are crucial for the long-term prospects and sustainable growth of the county (Meier \& Rauch, 2000).

Thus, if governments try to apply punitive procedures and better enforcement as to reduce unofficial economy, can arise serious problematic side effects (Feige \& Ott, 1999). In that way, such government measures could lower available financial resources income and increase labour costs, which would reduce consumption and lower living standard for a significant part of citizens (Karaic, 2002). For all mentioned, monitoring and managing of the unofficial economy involves a fine balance between the need to reduce the informal economy and the need to provide the society with the ability to thrive and establish long-term prospects (The Balkan Trust for Democracy, 2016).

\section{An Overview of Unofficial Economic Activities in the Service Sector in Selected Countries in South East Europe}

There are noteworthy specificities and many differences of unofficial economy in the service sector in each of the selected countries in South East Europe. The space and the attention reserved for each of the countries discussed in this paper depends on the volume of available researches conducted in each of them and on the importance of the informal economy for a particular country. SELDI (2016) displays 
main differences in the incidence of unofficial economy across SEE, including all the Western Balkans, Bulgaria and Croatia.

Albania - The existence of the unofficial economy is the resultant of several elements. The radical changes in the economic and political system caused the modifications in the situation on the labour market and citizens' income. Furthermore, there was a weak implementation of the laws and confusing tax policies with high costs. Finally, such circumstances created vacuum in the legal system (Demalija, 2017). The unofficial economy is present in different types of services, but also in transport (informal minibuses, buses, taxies and tracks), retail and construction. The blossoming of trade, based mostly on the import of goods, and fast development of informality in the service sector came because of the cessation in the official economy or their non-existence in the regular system. The uncontrolled population movement from rural areas to urban centres, particularly to the capital Tirana, has been one of the main side factors of the economic and political changes. As a result, a new labour force has appeared which could be employed mostly in the unofficial service sector without having almost any possibilities for legal work (Gerxhani, 2003). Furthermore, the situation was also deteriorated by continuous changes in the complicated tax system, so many entrepreneurs have stated that their fiscal evasion is a result of the present adverse tax policy (Gerxhani, 2001). The changing tax system with its high cost motivated individuals and/or business entities to hide a significant part of their business and income. Furthermore, corruption has been an important problem for the development and growth of private business entities. The policy regarding labour contracts between employers and employees is not clearly defined, so in different around 40-60\% of companies do not have labour contracts with their employees (SELDI, 2016). The unofficial labour market is becoming the competitor of the formal labour market. All employers can very easy find people to work without labour contracts (Zef et al., 1999). The prices offered by the unofficial sector are taxfree and free of other obligations like social contributions and in that way lower than prices in the regular economy. Nevertheless, unofficial sector has created competitive mechanisms within its structures. The government tries to implement and develop the conditions and possibilities so that being a part of the formal sector enables greater advantages than those by the unofficial sector. The government provides various incentives for informal entrepreneurs to legalize their activities, and for employees to formalise their employment. Mentioned process is slow and demands the patience of all actors (Mihes et al., 2011).

Bosnia and Herzegovina - The very complex and unclear government structure and the overlapping authorities and duties of various levels of government and their bodies and agencies make implementation of laws as well as application of coherent and targeted policies very complex and demanding. The provisions of old and new laws are often in conflict, while incompatible legal regulations exist in diverse parts 
of the country. The responsible inspection agencies are often organisationally and financially under-resourced and there is a lack the required coordination and collaboration between them (Mihes et al., 2011). The research by Soldo and Powell (2011) presents a case of informal services in education in Bosnia and Herzegovina. 32\% of respondents use private informal tutoring services in the final year of secondary school. Besides, the research shows that pupils mostly use services of informal private lessons in math (66\%), followed by tutoring in foreign languages (10\%) and in physics (9\%). A strong growth in the number of informal private tutoring is controversial and it may indicate that the public education system does not satisfy the needs of the pupils. Additionally, some teachers abuse their position by giving informal private tutoring lessons to the same pupils they teach in regular education. Soldo and Powell (2011) deem the causes of such situation are following: inappropriate and inefficient system of formal education; weak collaboration and cooperation between teacher, school, parent and pupils; a low level of trust in the education system, and, finally, changes in attitudes regarding the importance and value of education.

Bulgaria - Mostly in the first decade of transition, developing private sector faced various impediments for growth. The private entrepreneurs were confronted with high costs of dealing with the government bodies, unstable and complicated tax regulation, inefficient and coercive tax collection, serious macroeconomic instability, usually unclear government's policies and slow process of privatisation (Stanchev \& Bogdanov, 1997). All of these elements contributed to the development of unofficial business activities and an increase of informal labour in provision of different services. The obstacles for opening and running the business activities varied from one sector to another. They were very small in commerce where opening a shop, selling at an open-air market place or on the street did not require a specific license and permit. However, the number of needed licences and permits increased with the augmented sophistication of businesses activities. Even though there are benefits (primary as a buffer for social problems linked to transition) and costs to informal operations, according to Stanchev \& Bogdanov (1997), the total effect of the unofficial economy on the macro level in Bulgaria was mostly negative. The largest proportion of informal workers without labour contracts was recorded in the agriculture, followed by the trade sectors, while the service sector showed the smallest share (Kyle et al., 2001). Anyhow, there is a practice of the service sector to underreport number of employees and revenues with the intention to evade payment of taxes and contributions for social insurance. The share of interviewed persons who purchase undeclared products and services is higher than the EU27 average, while multiple services (e.g. private tutoring for the entrance exams for high school and foreign language lessons, domestic repairs, healthcare, cleaning and gardening, babysitting) are the most often underreported activities (Dzhekova \& Williams, 2014). Simultaneously, the low quality of basic public services such as pension insurance and health care undermines citizens' 
readiness to finance the services provided by the public system. In the circumstances of the serious mismatch between the formal and informal institutions and a lack of trust in government, the unofficial economy will probably record further high rates (Williams et al., 2014). As mentioned conditions are currently prevalent in Bulgaria, the deeply rooted and widespread unofficial economy will remain in the nearly future. Therefore, the country will for some time keep the embarrassing top position with the highest share of the unofficial economy in the EU (A.T. Kearney, 2013). CSD (2016) stressed that with EU membership and integration in the international value chains, informal activities in Bulgaria have tended to decline both in services and in other sectors. The reasons for participation in the unofficial activities have also changed, as more persons active in it are those from lower income groups, primarily employees with monthly salaries below EUR 500.

Croatia - The Centre for Marketing Research (CEMA, 1995) in 1995 realised a research of extra paid jobs without enquiring about the sum earned. An additional paid job was defined as any job making an income, outside the revenues from a permanent employment and regular economic activity, as well as earnings from own company or regular agricultural activity. Additionally, such informal jobs were examined from both sides: from the perspective of those who used the services or bought the goods from the persons to whom these activities were additional jobs and from the position of those who performed such services. In the observed year, members of approximately 360,000 households performed additional unofficial jobs. In this practise of earning were actively engaged members of one quarter of household in Croatia. Around $15 \%$ of households did some kind of additional activity regularly, while $9 \%$ of the households engaged in additional activities on non-regular basis. The hidden activities were more frequently realised in smaller towns with 2,000 to 10,000 inhabitants. By type of sectors, unofficial paid jobs were most frequent in agriculture (32\% of all households), followed by provision of intellectual services (teaching, translating) in $19 \%$ of households. Around $2 \%$ of households in Croatia (less than $10 \%$ of those performing additional paid jobs) were engaged in servicing machines and appliances, in production of particular goods (e.g. plastic, paper, clothes and other products) and in construction works (e.g. adaptation or building of housing and business properties). Other jobs, such as interior decorating (e.g. wall painting, house-and-woodwork flooring etc.), work in hotel and food service industry, renting (rooms or apartments) and giving personal services (e.g. hair dressing, pedicure, etc.) were much less frequent. Thus, approximately 360,000 households with about 530,000 members were engaged in performing additional unofficial paid jobs, which accounted for almost a half of the total number of the employed population in Croatia. On the side of users, the main reason for obtaining such services is lower price. This reason was the crucial factor for the fourth fifth of people who acquired this kind of service. Other reasons appeared far less important: for $11 \%$ of interviewed 
households the accessibility to persons performing these activities was easier, for $10 \%$ it was better quality and for $9 \%$ it was the only possibility to obtain a particular product or service. Lovrincevic et al. (2006) appraised the total amount of informal work (IW) in Croatia by applying two methods. The first one is the sum of particular forms of IW according to the methodology proposed by the Eurostat (N1-N7). The obtained results of such approach present a lower estimation threshold of IW. In the second approach, using DYMIMIC input method, the higher boundary of IW in Croatia is estimated. The average share of informal (hidden or underground) work in total GDP and Gross Additional Value (GAV) decreased from 12.4\% GDP (15.4\% GAV) in 1998 to $11.2 \%$ GDP (13.9\% GAV) in 2002. The economic sectors with the highest share of the UW in GAV in 2002 were Hotels and restaurants $(33.7 \%$ ) and Real estate leases and business services (31.7\%), but mentioned share was also high in the economic sector Other community, social and personal services (19.9\%). Jokic et al. (2013) analysed the reasons for the widespread use of informal private tutoring in Croatia. They believe that educational reform, which includes the implementation of standardised curricula together with increased complexity of assessment procedures, might cause parents' anxiety about their children's educational progress and in that way result in the increased usage of such services. Additional reason for informal private tutoring is the fact that the education system in Croatia is more oriented towards teacher rather than pupil-centred and it is insufficiently tolerant to slow learner. Many interviewed persons state that the curriculum in Croatia is extensive, dense and overloaded, even boring and irrelevant which stimulates or forces parents to seek informal private tutoring for their children.

FYR Macedonia - Using the Electricity Consumption method, Garvanlieva et al. (2012) assessed that the underground economy decreased from 34.1\% of GDP in 2000 to $23.4 \%$ in 2009. While in Other sectors (transport, households, agriculture etc.), the stated share was $34.1 \%$ of GDP in 2000, it decreased to $22.3 \%$ of GDP in 2009. Dzhekova et al. (2014) remind that a significant part in all economic activities is hidden, but this phenomenon in Macedonia is particularly prevailing in labour-intensive sectors such as domestic services, construction, food service, home cleaning, car repairs, tutoring, hairdressing and cosmetic services. Non-compliant practices are deeply rooted, so some $6.1 \%$ of adults work in the unofficial economy, while $17.7 \%$ buy undeclared goods and services. The oldest age group (individuals over the age of 65) was the least involved in buying on the informal market, while self-employed persons participated more than employed and jobless persons. Furthermore, male show higher demand for undeclared goods and services than female, while the same applied to rural areas in comparison with the population in the towns. The most obvious form of activities in the undeclared market is the purchase of the food from individual farmers, followed by house repairs and car services. Among other informal services, relatively often are beauty and hairdressing treatments, cleaning home 
services and IT assistance. The most important reason for purchasing of undeclared goods and services was the lower price (stated by $57 \%$ of interviewed persons), followed by faster services (about 16\%) and a better quality on informal market (about $13 \%$ of the respondents). According to the type of activities, $13 \%$ of undeclared workers had provided services of home maintenance, $10 \%$ look after the children, $8 \%$ had traded other goods or services, $7 \%$ were active in domestic cleaning, $6 \%$ IT assistance, $6 \%$ tutoring, $4 \%$ participated in serving of cars, while 3\% did gardening services (Bezeredi \& Williams, 2017). Working in the unofficial service sectors often means low salaries, performed precarious and hazardous activity, while health standards and occupational safety are not respected. The lack of educational and training opportunities prevents informal service workers from search for better-paid jobs in the provision of official services (ILO, 2015). For the national government an area of high priority is formalization of the unofficial economy. Several positive and praiseworthy measures were performed, like lowering the contribution rates for social security, introduction of a 'one-stop-shop' model for company registration and tax reforms (primarily simplification of the tax system and the acceptance of a lower tax base for registered individual farmers) (Garvanlieva et al., 2012). However, there is still a need and a space for additional activity for improving the relation between the citizens and the state, primarily enhancing mutual respect and trust.

Kosovo $^{1}$ - The registered unemployment rate is very high (around 48\%), while low official employment rate $(26 \%)$ is probably higher because of the significant part of population being active in the unofficial activities (Friedrich Ebert Stiftung et al., 2013). The World Bank (2010) and the ILO (2010) assess that more than a half of total employment is in the grey economy. Informality is particularly high by young workers, so almost three fourth of them are not insured in pension and healthcare system (Krasniq \& Topxhiu, 2012). The unofficial economy is mostly widespread in the service provision, construction, transport and tourism. The research by Riinvest Institute (2002) shows that $8.9 \%$ of respondents participate in unregistered business activities or handicrafts (e.g. construction and maintenance of houses, service and fixing of household equipment and cars). Complex and lengthy business registration and licensing procedures discourage official business activity, or at least push business entities into informal activities (Friedrich Ebert Stiftung et al., 2013). Transition from unofficial to formal economy is a long-lasting, complex and demanding task for Kosovo that requires commitment of all relevant political, social and economic actors. Fully aware of the deeply rooted and widespread unofficial economy (its share is assessed to almost 30\% of the GDP); the Government of Kosovo (2014) has proposed a national response and the strategic objectives to the identified risks of informal economy. They include raising public awareness on the impacts and on the prevention of informal economy; consolidation the prevention and fight against informal economy by enhancing accountability, transparency, good governance and social 
partnership. Finally, the goal is to enhance the capacity of the responsible institutions and develop national legislation framework to implement the international standards while simultaneously enable its efficient and effective implementation (Government of Kosovo, 2014).

Moldova - The deep economic and political transition of Moldova from a centrally planned socialist economy towards a market economy and independency has provided developmental prerequisites and ample institutional preconditions for the development of high levels of the unofficial economy. This transition started from the situation where unemployment and informality were being essentially banned in the Soviet era. These conditions rendered any informal employment for income illegal but at the same time created the need for massive self-help economy as public services were undersupplied and rationed. Then in the 1990s there was extremely low employment opportunities, precipitous fall in income and overreliance on remittance. All stated factors fuelling informality, particularly when coupled by a change in the national institutional framework (World Bank, 2009). The starting point and the trajectory of transition do seem to matter in the scope and the development of the informal economy in the service sector in Moldova. An experimental research of envelope wages among students (which are mostly employed in service sectors) in Moldova and Romania, has revealed that students in the former are almost twice as likely to be engaged in obtaining envelope wages, with low incomes one of the decisive factors (Horodnic, Rodgers, Williams, \& Momtazian, 2018). The International Labour Organization (ILO, 2016) in a comprehensive review of the informal sector in Moldova as the main causes of informality mentions several factors. They include, among others, the low costs of staying informal, the high costs of formalisation and the poor quality of public services, what discourages the payment of taxes and social contributions. The ILO deems that the share of the unofficial economy was $23.1 \%$ of GDP in 2013. In the same year, around one third of the total employed population had an informal job, mostly in the agricultural sector. Some $12 \%$ of those informally employed were in the trade, hotels and catering, while another 3\% were in communications and transport, which all combined can be regarded as service sectors. However, the exhaustiveness of national accounts method used in this assessment usually underestimates the level of informal economic activity primarily it does not fully include informal employment in household services and self-help (CSD, 2011). Nevertheless, Moldova has relatively good data coverage on unofficial economy due to the combination of applied direct methods (in the form of surveys according to the ILO unified approach) as well as by indirect methods (such as the one of the National Bureau of Statistics) (Pfau-Effinger, 2017). The combination of approaches showed that informal employment in Moldova was roughly equally distributed between undeclared work in formal enterprises (35.1\%), employment in unofficial sector enterprises (32.5\%), and employment in the subsistence economy (31.3\%). 
Montenegro - Prior to transition process, informal work was around 5\% of GDP with vast majority of informal activities consisting of selling of agricultural products and home repairs (Mihes et al., 2011). Montenegrin Employers Federation and Kostic (2014) state that the absence of rule of law and inefficient law implementation, high business costs, aside from some external factors (e.g. war, sanctions), have contributed to widespread unofficial work in Montenegro. In the period from 1990s to 2000s, the share of informal economic activities ranged from $35 \%$ to $60 \%$ of GDP. In early 2000 s, almost $40 \%$ of workers employed in hospitality, trade and construction were working informally. The decrease of informal labour was recorder in 2005 when unofficial economy was $25 \%$ of GDP. The sectors with highest share of informal work were commerce (38.1\%), agriculture production (18.2\%) and tourism and food preparation (19.1\%). According to the recent survey by UNDP (2016), the level of informal economy was rather constant and the entire value of informal activities was equal to a quarter of GDP in 2014. Furthermore, the same report showed that more than one third of Montenegro companies performed certain level of business activities within the unofficial economy. The largest number of informal labour is recorded in construction and services sector. More than $43 \%$ of firms active within services sector employ individuals on informal basis. UNDP (2016) believes that services like renting, transportation and financial mediation include above the average level of unofficial business activities. The key impediments to formality are fiscal and parafiscal burden in addition to complex and inflexible regulation of the labour market (particularly calculation of wages and salaries, high cost of firing and severance payment). The government in cooperation with all relevant actors is trying to strengthen institutions and reform the labour market regulation, primarily with introduction of more flexible solutions.

Romania - Although the existence of a "second" or informal economy was known under the centrally planned socialistic system, real discussion on this issue has started since transition to market economy. In 2008, informal labour represented between $20 \%$ and $50 \%$ of total employment in the country depending on the applied definitions and methodology (Parlevliet and Xenogiani, 2008). There are at least three factors important for the presence of the unofficial labour. The first one is the disruptions caused by the transition from centrally planned socialistic economy to market political and economic system. The second group of factors is related to institutional weakness, inefficiencies and gaps. The third group consists of behavioural specifics, such as the low level of trust in the society, the disrespect of the rule of law and weak state. Various studies using different assessment methods found that the sectors most exposed to unofficial labour were agriculture, construction, and trade, followed by services in the hotel and restaurant business. In Romania, there are comprehensive estimates of the size and development of the unofficial work. Based on two household surveys from September 1996 and July 2003, Albu (2004) believes that income form 
the informal work declined from $23.6 \%$ to $22.7 \%$ of the total household income. The key cause for the underground economy was relatively high tax burden. Davidescu, Strat, and Paul (2015) noted that the unofficial part represented 19\% of the official economy in Romania in 2000 . Then it declined until 2008 , followed by slight rise and stood at 13\% of GDP in 2014. Litra (2016) finds that the underground economy in Romania consists of undeclared work (two thirds from the total) and unreported income (around one third). Citing Schneider, Raczkowski, Mroz (2015) notes that the shadow economy in Romania has declined from 33.6\% of GDP in 2003 to $28.9 \%$ in 2014 but it remains the second highest share in the EU. In line with other findings, there has been evidence that foreign direct investment in Romania has caused a decline in the unofficial economy (Davidescu \& Strat, 2015). As services are a significant part of the national economy, this finding implies that the decline in the unofficial economy might be expected to be lower or to occur with lower rates in services than in tradable goods' industries.

Serbia - After the downfall of one-party political system, transition from planned economic and the disintegration of the former federal state at the beginning of 1990s, Serbian economy was exposed to serious economic and social problems. They included international sanctions that were implemented in 1992, weak economy that operated almost in the war conditions, hyperinflation that swept away any possibilities for economic growth and, finally, numerous law changes that caused the legal instability. All mentioned factors produced fruitful conditions for the development of the unofficial economy. As stated by Arandarenko (2015a), during that period even the official authorities were inclined to use informal channels in some aspects of economic activities, like foreign trade and customs. The share of the unofficial economy was at the peak in 1993 with 54.4\% of GDP (Arandarenko, 2015a). After that year, there was the decrease in the volume of unofficial economic activities. Krstic et al. (1998) calculated that the share of informal economy decreased by almost one fifth in a four years period, so the mentioned share was 34.5\% of GDP in 1997. Further reduction of the unofficial economy was recorded after 2000s when a real economic transition to a market economy and reforms in privatisation and restructuring were initiated. Almost the entire legislation (particularly labour legislation) has been rewritten in order to support the transition to a market economy, but also with a view to complying with the relevant regulations, requirements and standards of European Union and ILO. Using MIMIC method, FREN (2013) estimates that in the period 2001-2010 the share of the unofficial economy decreased by only $3.1 \%$. The possible reason is primarily related to the introduction of inadequate tax system (e.g. high tax burden at low wage levels), which demotivated individuals and businesses from entering into formal economic activities (Krstic \& Corbanese, 2009; Arandarenko, 2015a). Krstic and Corbanese (2009) also state that in the period from 2002 to 2007 the share of informal workers among youth increased by almost $10 \%$. During 
the same period, the level of informal labour in the services sector decreased by $13 \%$, while significantly grew in agriculture and industry sectors (Krstic \& Sanfey, 2010). The survey from 2012 of 1.251 Serbian firms shows that business entities from service sector are almost two times less likely to engage in informal economic activities relative to companies from construction sector (FREN, 2013). The share of business entities in food preparation and other services active in unofficial economy is $33.1 \%$ and $25 \%$, while the percentage of companies employing workers informally in these two sectors is $22.4 \%$ and $21.4 \%$ (Krstic \& Radulovic, 2015). The same authors indicate that the share of employees receiving envelope wages in Serbia is highest in construction, followed by other services, primarily food preparation. According to Schneider et al. (2015), 30.5\% of firms in food preparation and $25.9 \%$ of companies in other types of services are engaged in unofficial activities; primarily lower reporting of paid wages. The official data for 2016 by Statistical Office of the Republic of Serbia (2016) show that the level of informal labour is $22 \%$ of total employment. Most of the informally employed persons are 25 to 54 years old. A significant part of informal work is realised by falsely (bogus) self-employed persons that work without any additional employees. The sectors with the highest levels of informally workers are agriculture and service sector. 39.03\% of the total number of informal employees works in the service sector, which is equal to $11.03 \%$ of the total number of formally employed people in Serbia (Statistical Office of the Republic of Serbia, 2016). According to the Labour Inspectorate Annual Report (2011), the informal employment is widespread in construction, trade, industry, food preparation and tourism, crafts and home repairs and provision of personal services. The labour inspectors also stated that the informal workers performing economic activities in their homes provide various types of services such as sewing, shoemaking, woodworking, hairdressing and other beauty services (Arandarenko, 2015b).

\section{Conclusion and Recommendations}

This paper provides an overview of the presence and the traits of the informal labour in the service sector in the selected South-Eastern European counties based on a review of available studies. Our goal was to shed an additional light to the mentioned phenomenon and to fill-up the existing literature gap. There are various forms of the informal activities, from informal tutoring to personal services like hairdressing and beauty services. The realised researches suggest that informal work in services sector tends to be generally higher than the one in tradable goods' sectors, as services are mostly consumed at the time of their preparation and are much easier to conceal. From all available analytical sources, it is evident that it is much more important to resolve the causes of informal services than to punish for the participation in such activities. 
It is obligatory to simplify the procedures for the formalization of informal work and unofficial business activities, to insure stable and simple tax system, to lower tax burden and decrease or solve the unnecessary state regulatory complexity system. Furthermore, there is a need for further liberalisation of the product and service market as well as the simplification of the legislation and procedures for establishing small and medium enterprises. Public campaigns for raising awareness are important and appreciated to highlight unsociable behaviour and to stress the negative consequences of the informal work and unofficial economy. It is unlikely that informality would decline sustainably without measures to build higher trust in society and towards state institutions.

\section{NOTES}

${ }^{1}$ This designation is without prejudice to positions on status and is in line with UNSCR 1244.

\section{REFERENCES}

Albu, L. (2004). Estimating the Size of the Underground Economy in Romania. Institute of Economic Forecasting, Bucharest: Romanian Academy.

Arandarenko, M. (2015a). The Shadow Economy: Challenge to Economic and Social Policy. In Krstic, G. \& Schneider, F. (ed.) Formalizing the Shadow Economy in Serbia, London: Springer Open, 5-12.

Arandarenko, M. (2015b). Analysis of the administrative Capacity of the Institutions in Charge of Overseeing the Operations of Business Entities. In Krstic, G. and Schneider, F. (ed.) Formalizing the Shadow Economy in Serbia, London: Springer Open, 109-122.

A.T. Kearney, 2013. The Shadow Economy in Europe: Using the Payment System to Combat the Shadow Economy, London: A.T., Kearney. Available on https://www.atkearney.com/documents/10192/1f89864d-903f-4683-b6e4-df57e223a4d7.

Bacchetta, M., Ernst, E., \& Bustamante, J. P. (2009). Globalization and informal jobs in developing countries, Geneva: The International Labour Office and the Secretariat of the World Trade Organization.

Balkan Trust for Democracy (2016). The Shadow Worker - Hidden Economy and Undeclared Labour in Macedonia, Albania and Kosovo. Policy Brief No. 38, Tirana: Centre for Research and Policy Making, Institute for Democracy and Meditation, Democracy for Development.

Bejakovic, P. (2015). A revision of the shadow economy in Croatia: causes and effects, Economic Research, 28(1), 422-440.

Bejakovic, P. (2017). How to measure the unmeasurable: Project Grey developing capacities and capabilities for tackling undeclared work, Croatian Review of Economic, Business and Social Statistics (CREBSS), 3 (2), 20-38.

Bezeredi, S., \& Williams, C. (2017). Illegitimate Economic Practices in FYR Macedonia. GREY Working Paper No.10, Sheffield, Zagreb: University Management School and Institute of Public Finance. 
Brezinski. H. (1983). The Second Economy in the Soviet Union and its Implications for Economic Policy. In Gaertner, W., \& Wenig, A. (ed.) The Economics of the Shadow Economy Proceedings of the International Conference on the Economics of the Shadow Economy, 15, Springer, Berlin, Heidelberg.

Bowles, R. A. (1999). Tax Policy, Tax Evasion and Corruption in Economies in Transition. In Feige, E. \& Ott, K., (ed.) Underground Economies in Transition, Aldershot: Ashgate Publishers, 67-86.

Bryson, B. (2004). Made in America, New York: HarperCollins.

Cassel, D., \& Cichy, U. (1987). The shadow economy and economic policy in East and West: a comparative system approach. In Alessandrini, S., \& Dallago B. (ed.) The Unofficial Economy, Andershot: Gower, 127-146.

CSD (2013). The hidden economy in Bulgaria: 2011 - 2012, Policy brief No 37, January 2013, Sofia: Center for the Study of Democracy.

CSD (2016). The hidden economy in Bulgaria: 2015 - 2016, Policy brief No 64, September 2016, Sofia: Center for the Study of Democracy.

Dallago, B. (1987). The underground economy in the West and the East: a comparative approach. In Alessandrini, S., \& Dallago, B. (ed.) The Unofficial Economy, Andershot: Gower, 147-163.

Davidescu, A., \& Strat, V. (2015). Shadow Economy and Foreign Direct Investments: an Empirical Analysis for the Case of Romania, ECOFORUM, 4(2), 265-283.

Davidescu, A., Strat, V., \& Paul, A. (2015). Revisiting the Size of the Romanian Informal Economy Using the Gutmann Approach, Procedia Economics and Finance, 23(2), 1037-1045.

Demalija, R. (2017). Informality vs Politics; The Interactions Between Politics and Social Behaviour in Albania, a Retardment for the EU Integration Process, European Journal of Multidisciplinary Studies, 4(4), 27-30.

Dzhekova, R., Franic, J., Mishkov, L., \& Williams, C. C. (2014). Tackling the Undeclared Economy in FYR Macedonia, A baseline assessment, GREY Working Paper No. 3, University of Sheffield.

Dzhekova, R., \& Williams, C. C. (2014). Tackling the Undeclared Economy in Bulgaria: A baseline report, GREY Working Paper No. 1, University of Sheffield.

Easton, S. (2001). The Size of the Underground Economy: A Review of the Estimates. Available on https://www.researchgate.net/publication/251857713_The_Size_of_the_Underground_ Economy_A_Review_of_the_Estimates

Ericson, R. (1984). The "Second Economy" and Resource Allocation under Central Planning, Journal of Comparative Economics, 8(17), 1-24.

Feige, E. L. (1979). How Big is the Irregular Economy? Challenge, Nov-Dec., 5-13.

Feige, E. L. (1983). The Meaning of the "Underground Economy" and the Full Compliance Deficit. In Gaertner, W., \& Wenig, A. (ed.) The Economics of the Shadow Economy, Heidelberg: Springer Verlag, 19-37.

Feige, E. L. (1987). The Anatomy of the Underground Economy. In Alessandrini, S., \& Dallago, B. (ed.) The Unofficial Economy, Andershot: Gower, 83-106.

Feige, E. L. (1990). Defining and Estimating Underground and Informal Economies: The New Institutional Economics Approach, World Development, 18 (7), 989-1002.

Feige, E. L. (1997). Underground activity and institutional change: productive, protective and predatory behaviour in transition economies. In Nelson, J. M., Tilly, C., \& Walker, L. (ed.) Transforming post-communist political economies, Washington DC: National Research Council, 19-34.

Feige, E. (1999). Underground Economies in Transition: Noncompliance and Institutional Change. In Feige, E., \& Ott, K., (ed.) 1999. Underground Economies in Transition, Aldershot: Ashgate Publishers, 11-28. 
Feige, E., \& Ott, K. (1999). Underground Economies in Transition, Aldershot: Ashgate Publishers.

Feige E. L., \& Urban, I. (2008). Measuring underground (unobserved, non-observed, unrecorded) economies in transition countries: Can we trust GDP?, MPRA Paper No. 7345, Munich: Munich Personal RePEc Archive.

Franicevic, V. (1999). Political Economy of the Unofficial Economy: the State and Regulation. In Feige, E., \& Ott, K. (ed.), Underground Economies in Transition, Aldershot: Ashgate Publishers, 117-140.

Franicevic, V., \& Kraft, E. (1996). Economic development in Croatia: Is Croatia facing a growth impasse? Paper presented at the conference Economic Reconstruction and Development Policies in the Yugoslav Successor States, School for Policy Studies, Bristol: Mimeo, 1-40.

Franz, A. (1984). Schatzungen der hidden economy in Österreich auf der Basis offizieller Statistiken (Estimation of Hidden Economy in Austria based on the Official Statistics). In Skolka, J. (ed.) Die andere Wirtschaft: Schwarzarbeit and Do-it-yourself in Österreich, Vienna: Signum, 83-99.

Friedrich Ebert Stiftung (FES) Office in Prishtina, the Kosovo Foundation for Open Society (KFOS), \& Riinvest Institute for Research and Development (2013). To Pay or Not To Pay: A Business Perspective of Informality in Kosovo, Pristina: Friedrich Ebert Stiftung and Riinvest Institute.

FREN (2013). The Shadow Economy in Serbia - New Findings and Recommendations for the Reform. Belgrade: FREN.

Galić Nagyszombaty, A. (2012). Unofficial economy in Croatia: Estimation methods and results, Methods and Results. Ekonomski pregled, 3(1), 734-762.

Garvanlieva, V., Andonov, V., \& Nikolov, M. (2012). Shadow Economy in Macedonia. Skopje: Centre for Economic Analyses.

Gershuny, J. I. (1979). The Informal Economy - its Role in Post-Industrial Society. Future, 11(1), 3-15.

Gerxhani, K. (2001). The informal sector in transition: tax evasion in an institutional vacuum. Amsterdam: Tinberger Institute.

Gerxhani, K. (2003). Politico-economic institutions and the informal sector in Albania. Amsterdam Institute for Advanced Labour Studies (AIAS) Research Report 03/12, Amsterdam: Amsterdam Institute for Advanced Labour Studies.

Gibson, B. (2013). Informality in manufacturing and economy. Development Policy, Statistics and Research Branch Working Paper 8/2013, Vienna: United Nations Industrial Development Organization - UNIDO.

Glas, M. (1988). Razcvet sive ekonomije v sedemdesetih letih - Pogled na razloge in dejanske razmene (The boom of the grey economy in the 1970s - A look at the reasons and actual scope). In Glas, M., Kukar, S., Simoncic, M., \& Bicanic, I., Siva ekonomija v svetu in v Jugoslaviji (Grey economy in the World and in Yugoslavia), Ljubljana: Delavna enotnost.

Glinkina, S. (1999). Peculiarities of the unofficial economy during the transition. In Feige, E. \& Ott, K. (ed.) Underground Economies In Transition, Aldershot: Ashgate Publishers, 101-116.

Government of the Republic of Kosovo (2014). National strategy of the Republic of Kosovo for the prevention of and fight against informal economy, money laundering, terrorist financing and financial crimes 2014-2018. Prishtina: Government of the Republic of Kosovo.

Grossman, G. (1977). The "Second" Economy of the USSR, Problem of Communism, 26(5), 25-40.

Grossman, G. (1985). The Second Economy in the USSR and Eastern Europe: A Bibliography. Berkeley-Duke Occasional Papers No. 1, Berkeley: University of California Duke University.

Grossman, G., \& Treml, G. V. (1987). Measuring hidden personal incomes in the USSR. In Alessandrini, S., \& Dallago, B. (ed.) The Unofficial Economy, Andershot: Gower, 285-301.

Gutmann, M. P. (1985). The Subterranean Economy, Redux. In Gaertner, W., \& Wenig, A., (ed.) The Economics of the Shadow Economy, Heidelberg: Springer, 1-18. 
Harding, P., \& Jenkins, R. (1989). The Myth of Hidden Economy, Towards a New Understanding of Informal Economic Activity, Milton Keynes, Philadelphia: Open University Press.

Horodnic, I., Rodgers, P., Williams, C., \& Momtazian, L. (2018). The Informal Economy: Exploring Drivers and Practices, Routledge: New York.

International Labour Organisation (ILO) (2002). Decent work and the informal economy. Report VI, International Labour Conference, 90th Session, Geneva: International Labour Organisation.

International Labour Organisation (ILO) (2010). Profile of the Social Security System in Kosovo. Budapest: International Labour Organisation.

International Labour Organisation (ILO) (2014). Transitioning from the informal to the formal economy. Geneva: International Labour Organisation.

International Labour Organisation (ILO) (2015). Decent Work Country Programme of the Former Yugoslav Republic of Macedonia 2015-2018. Geneva: International Labour Organisation.

International Labour Organisation (ILO) (2016). The Informal Economy in Republic of Moldova: A Comprehensive Review. Geneva: International Labour Organisation.

Jankov, Lj. (1997). Monetaristicki pristup nesluzbenom gospodarstvu (The Monetary Form of the Unofficial Economy), Financijska praksa, 21(1-2), 157-168.

Johnson, S., Kaufmann, D., \& Shleifer, A. (1997). The Unofficial Economy in Transition, Brookings Papers on Economic Activity, 2, 159-239.

Jokic, B., Bregvadze, T., Kazimzade, E., Kirss, L., Ristić Dedić, Z., Soldo, A. (2013). Emerging from the Shadow: A Comparative Qualitative Exploration of Private Tutoring in Eurasia. Zagreb: Network of Education Policy Centres.

Jutting, J., \& de Laiglesia, J. R. (2009). Is Informal Normal? Towards More and Better Jobs in Developing Countries. Paris: OECD.

Karaic, N. (2002). Siromastvo i nesluzbeno gospodarstvo u Hrvatskoj - kvalitativni aspekti. (Poverty and Underground Economy in Croatia - Qualitative Aspects). Financijska teorija i praksa, 26(1), 273.299.

Kaufmann, D., \& Kaliberda, A. (1996). Integrating the unofficial economy into the dynamics of post-socialist economies: a framework of analysis and evidence. In Kaminski, B. (ed.) Economic Transition in Russia and the New States of Eurasia, New York London: M.E. Sharpe Armonk, 81-120.

Kaufmann, D., \& Siegelbaum, P. (1996). Privatization and Corruption in Transition Economies, Journal of International Affairs, 50 (2), 419-458.

Kyle, S., Warner, A., Dimitrov, L., Krustev, R., Alexandrova, S., \& Stanchev, K. (2001). The Shadow Economy in Bulgaria. Sofia: Harvard University, Agency for Economic Analysis and Forecasting and Institute for Market Economics.

Krasniq, X. F., \& Topxhiu, M. R. (2012). The Informal Economy in Kosovo: Characteristics, Current Trends and Challenges, Journal of Knowledge Management, Economics and Information Technology, 2(2), 1-25.

Krstic, G., Dinkic, M., Hadzic, M., Labus, M., \& Reilly, B. (1998). Analysis of the grey economy in the FRY with estimates of its volume for 1997 and recommendations for its legalisation. Belgrade: Economics Institute Belgrade.

Krstic, G., \& Corbanese, V. (2009). In search of more and better jobs for young people in Serbia. ILO Working Papers 2009/1. Geneva: ILO.

Krstic, G., \& Sanfey, P. (2010). Earning inequality and the informal economy: evidence from Serbia. Working Paper No. 114, European Bank for Development and Reconstruction.

Krstic, G., \& Radulovic, B. (2015). Shadow Economy in the Business and Entrepreneurial Sector. In Krstic, G. \& Schneider, F. (ed.) Formalizing the Shadow Economy in Serbia, London: Springer Open, 77-100. 
Labour Inspectorate (2011). Annual Report. Belgrade: Labour Inspectorate of the Republic of Serbia. Litra, A. (2016). The Underground Economy in Romania, Bulletin of the Transilvania University of Brasov, Series V: Economic Sciences, 9 (58), 229-236.

Lovrincevic, Z., Maric, Z., \& Mikulic, D. (2006). Maastrichtski kriteriji i ukljucivanje sive ekonomije - slucaj Hrvatske (Maastricht criteria and the inclusion of the underground economy - The case of Croatia). Privredna kretanja i ekonomska politika, 16 (106), 28-65.

Lovrincevic, Z., Mikulic, D., \& Niksic-Paulic, B. (2002). The official statistics approach to an Estimate of the size of the underground economy. Paper presented at the Institute of Public Finance international Conference "Unofficial activities in transition countries: Ten years of experience", Zagreb, October, 2002.

Lovrincevic, Z., Mikulic, D., \& Galic Nagyszombaty, A. (2011). Unofficial economy in Croatia and the impact of the economic recession on the unofficial economy. In Reic, Z., \& Simic, V. (ed.), Conference proceedings challenges of Europe: Growth and competitiveness reversing the trends. Split: University of Split, Faculty of Economics, 479-908.

Madzarevic-Sujster, S., \& Mikulic, D. (2002). An estimate of the underground economy via the national accounts system. Paper presented at the Institute of Public Finance international Conference "Unofficial activities in transition countries: Ten years of experience", Zagreb, October, 2002.

Meier, G. M., \& Rauch, J. E. (2000). Leading Issues in Economic Development. New York and Oxford: Oxford University Press.

Mihes, C., Popova, N., \& Roch, S. (2011). A comparative Overview of Informal Employment in Albania, Bosnia and Herzegovina, Moldova and Montenegro. Geneva: International Labour Organization.

(MEF), \& Kostic, V. (2014). Informal Economy in Montenegro - The enabling environment for sustainable enterprises in Montenegro. Podgorica: Montenegrin Employers Federation.

Nastav, B., \& Bojnec, S. (2007). The shadow economy in Bosnia and Herzegovina, Croatia, and Slovenia: the labour approach. Eastern European Economics, 45(1), 29-58.

Center for the Study of Democracy, 2011. The Hidden Economy in Bulgaria and the Global Economic Crisis. Center for the Study of Democracy: Sofia.

O’Hearn, D. (1980). The Consumer Second Economy. Soviet Studies, 32(2), 218-243.

Organisation for Economic Corporation and Development (OECD) (2002). Measuring the Non-Observed Economy. A Handbook, Paris: OECD.

Organisation for Economic Corporation and Development (OECD) (2007). Glossary of Statistical Terms. Paris: OECD.

Parlevliet, J., \& Xenogiani, T. (2008). Report on Informal Employment in Romania. OECD Development Centre, Working Paper No. 271, Paris: Organisation for Economic Cooperation and Development.

Perry, G., Maloney, W., Arias, O., Fajnzylber, P., Mason, A., \& Saavedra-Chanduvi, J. (2007). Informality: Exit and exclusion. Technical Report No. 40008, Washington, D.C.: World Bank.

Pfau-Effinger, B. (2017). Informal employment in the poor European periphery. International Journal of Sociology and Social Policy, 37(7/8), 387-399.

Riinvest Institute (2002). Labour Market and Unemployment in Kosovo. Prishtina: Riinvest Institute.

Schneider, F. (2005). Shadow Economies around the World: What Do We Really Know? European Journal of Political Economy, 21 (3), 598-642.

Schneider, F. (2011). Handbook on the Shadow Economy. Cheltenham: Edward Elgar Publishing.

Schneider, F. (2012). The Financial Flows of Transnational Crime and Tax Fraud in OECD Countries: What Do We (Not) Know? Available at http://www.econ.jku.at/members/Schneider/files/publications/2012/FinancialFlows_TaxFraud.pdf 
Schneider, F. (2013). Size and development of the shadow economy of 31 European and 5 other OECD countries from 2003 to 2013: a further decline. Available at: http://www.econ.jku.at/members/Schneider/files/publications/2013/ShadEcEurope31_Jan2013.pdf 40.

Schneider, F., Enste, D. (2000). Shadow Economies around the World: Size, Causes, and Consequences. Available at https://www.imf.org/external/pubs/ft/wp/2000/wp0026.pdf

Schneider, F., Krstic, G., Arsic, M., \& Randjelovic, S. (2015). What is the Extent of Shadow Economy in Serbia? In Krstic, G., \& Schneider, F. (ed.) Formalizing the Shadow Economy in Serbia, London: Springer Open, 47-76.

Schneider, F., Raczkowski, K. and Mroz, B., 2015. Shadow Economy and tax evasion in the EU. Journal of Money Laundering Control, Vol. 18 (1), pp. 34-51.

SELDI, 2016. Shadow Power: Assessment of Corruption and Hidden Economy in Southeast Europe. Sofia: SELDI. Available at: http://seldi.net/fileadmin/public/PDF/Publications/RAR_2016/ SHADOW_POWER_EN_FINAL.pdf

Shelley, L.I. (1983). Law and the Soviet Second Economy. Research in Law, Deviance and Social Control, 5(34), 3-24.

Shelley, L.I. (1990). The Second Economy in the Soviet Union. In Loš, M., The Second Economy in Marxist States, Hong Kong: Macmillan.

Soldo, A., \& Powell, S. (2011). The Phenomenon of Private tutoring - Possible Solutions: The case of Bosnia and Herzegovina. Sarajevo: Promente.

Stanchev, K., \& Bogdanov, L. (1997). Special features of Bulgarian informal Sector. International Workshop “The Importance of Unofficial Economy In Economic Transition”, Zagreb, Institute of Public Finance.

Standing, G. (1991). Introduction. In Standing, G. (ed.) In search of flexibility, The new Soviet labour market, Geneva: International Labour Organisation.

Statistical Office of the Republic of Serbia (2016). Bilten: Anketa o radnoj snazi u Republici Srbiji. Belgrade: Statistical Office of the Republic of Serbia.

Stefanov, R., Williams, C. C., \& Rodgers, P. (2017). Tackling Undeclared Work in the FYR of Macedonia: Knowledge-Informed Policy Responses. GREY Policy Brief, No. 2, Sofia/Sheffield: Vitosha Research and Sheffield University Management School.

Sweezy, M. P. (1980). Post-Revolutionary Society, Monthly Review, 118(1), 45-61.

UNDP (2016). Informal work from challenges to solutions. Podgorica: DPC.

Vincensini, C. (2001). Is path dependence a useful concept to analyse the evolution of ownership structures in Central Europe? A theoretical and empirical discussion. Paper prepared for the conference "Institutions in Transition" organised by IMAD, Otocec, Slovenia, 13-14 July 2001.

Williams, C. C. (2005). The undeclared sector, self-employment and public policy, International Journal of Entrepreneurial Behaviour \& Research, 11(4), 244 - 257.

Williams, C. C. (2011). A critical evaluation of competing representations of informal employment: some lessons from England. Review of Social Economy, 69 (2), 211-237.

Williams, C. C. (2014). Confronting the shadow economy: evaluating tax compliance and behaviour policies. Cheltenham, United Kingdom: Edward Elgar.

Williams, C. C., \& Martínez, A., (2014). Explaining cross-national variations in tax morality in the European Union: an exploratory analysis, Studies of Transition States and Societies, 6 (1), 5-18.

Williams, C. C., \& Renooy, P. (2008). Measures to tackle undeclared work in the European Union. Dublin: Eurofound.

Williams, C. C., \& Renooy, P. (2013). Tackling undeclared work in 27 European Union Member States and Norway: Approaches and measures since 2008. Dublin: Eurofound.

Williams, C. C., Franic, J., \& Dzhekova, R. (2014). Explaining the undeclared economy in Bulgaria: an institutional asymmetry perspective, South East European Journal of Economics and Business, 9 (2), 33-45. 
Williams, C. C., \& Schneider, F. (2016). Measuring the global shadow economy: the prevalence of informal work and labour. Cheltenham, UK Northampton, MA: Edward Elgar Publishing.

Williams, C. C., Baric, M., \& Renooy, P. (2013a). Tackling Undeclared Work in Macedonia, Dublin: Eurofound.

Williams, C. C., Baric, M., \& Renooy, P. (2013b). Tackling Undeclared Work in Montenegro, Dublin: Eurofound.

Wolff, E. N. (1983). The Disappearance of Domestic Servants and the Underground Economy. In Wulf, G., \& Wenig, A. (ed.) The Economics of the Shadow Economy Proceedings of the International Conference on the Economics of the Shadow Economy, Bielefeld: University of Bielefeld, 316-329.

World Bank (2009). Moldova Country Profile. Washington, DC: World Bank, International Finance Corporation.

World Bank (2010). Kosovo - Unlocking growth potential: strategies, policies, actions: a country economic memorandum. Washington, DC: World Bank.

Zef, P., Auron, P., \& Muco, L. (1999). Underground Economy in Albania. National Conference: Issues of Economic Growth in Albania, Tirana, 12-13 March 1999. 